\title{
ERRATUM
}

\section{To the article}

\section{"Content of HLA-G+ T Cells in the Peripheral Blood from Healthy Women and Breast Cancer Patients"}

by E. O. Ostapchuk, Yu. V. Perfil'eva, Sh. Zh. Talaeva, N. A. Omarbaeva, and N. N. Belyaev, Vol. 159, No. 5, pp. 649-651, September, 2015

The correspondence address should be: katyostapchuk@gmail.com. 